attempts in the past eight years have proved abortive. The agreement inaugurated in Washington recently may change the whole picture; or it may not.

The new Head of the Department, Ato Teshome Ashine, has been in office only one year. Ethiopia is huge and funds are short. Indeed, the Department budget is less than E\$1 million. The situation would be helped if so many of the staff were not concentrated at headquarters in Addis A baba-50 out of a total of 150. The Awash and Simien parks are tolerably staffed, Omo and the Rift parks halfstaffed, and the rest have nobody. Early this year, Awash Park had 14,000 cattle in it. The national parks have no regulations despite years of promises. Nevertheless, the overall situation is much better than it was a few years ago.

The General Manager's immediate contribution to the skin trade was to circulate a leaflet to tourists on arrival in Ethiopia asking them to help in stopping the trade by not buying skins; he hopes to try to control the trade sufficiently to reduce it to a trickle in two years. This may be preferable to an outright ban, which could well be impossible to enforce in a country with the size and enforcement resources of Ethiopia. (In the southern states of the USA over 100,000 alligators are allegedly poached every year.) But a regulated trade, while it could bring considerable financial benefit to Ethiopia and help the image of wildlife in this emergent country, could only be operated effectively with the support of consumer countries, and the attitude of several European countries has already been noted. Japan's response is likely to be pragmatic, and despite protestations to the contrary, the recent court case involving a majority of major US furriers (see Oryx, May 1973, page 7) casts doubt on the good faith of the fur merchants there.

\title{
References
}

BROWN, L. H. and URBAN, K. 1970. Bird and Mammal Observations from the Forests of South-western Ethiopia. Walia 3: 13-40.

MARIAM, M. W. 1970. An Atlas of Ethiopia. Addis Ababa, 84 pp.

continued from next page

The mere production of these booklets (the mammal one was first published in 1967) by such a wide range of often diverse interests is an achievement in itself and a good justification for publication. The law is spelt out simply and clearly, and upheld by all the interests represented, including the Gamekeepers' Association. Those of us who work in the countryside know how often it is broken, and that the use of poisons for destroying raptors is increasing rather than diminishing. The problem now is how to get these booklets into the hands of the people who should read them. They deserve the widest publicity, and conservation organisations must seek the widest distribution for them. All members of the FPS in UK should read and keep a copy themselves and give away copies freely to countryside acquaintances.

DAVID JENKINS 


\section{On Managing Predators}

\section{Predatory Birds in Britain}

Predatory Mammals in Britain,-revised edition. Council for Nature, $35 p$ each, obtainable from FPS, c/o The Zoo, London NW1 4RY.

These two booklets about the management of those mammal and bird predators that conflict with man's interests are aimed at all who use the countryside-landowners, farmers, gamekeepers, foresters, naturalists, and anyone who comes up against predator problems in everyday life. They were prepared by working parties representing farming, sporting and conservation organisations, including the FPS, with assessors from the Home Office, Nature Conservancy, Forestry Commission and Ministry of Agriculture. They show that these diverse interests have agreed a policy for managing predators within the law; they also make a plea for moderation in dealing with those predators which sometimes conflict with sport or farming.

The main points are that the sizes of game populations are determined much more by the quality of the habitat than by the number of predators living in it. When the control of mammal predators is necessary it should be selective, and the law about the protection of birds of prey should be upheld; these in particular are at risk from the effects of pesticides, and 'all concerned should seek by every means to ensure that the relevant laws are fully understood and observed'; these laws are summarised. A drawing accompanies the notes on each of 11 mammals and 45 birds, which include description, distribution, behaviour and food, with hints on avoiding conflicts and means of control when necessary. The mammal booklet also describes other methods of preventing damage.

The degrees of bird protection are described as 'ordinary'-penalty for molestation $£ 5$ - or 'special'- penalty $£ 25$ and/or imprisonment; and it is emphasised that all the true birds of prey are protected and that licences for control can only be obtained after application to the Secretary of State. The fact that some specially protected birds of prey take game birds (e.g. golden eagle, hen-harrier) is not concealed, but it is made quite clear that, whereas application for redress may be made for serious damage to lambs, 'control is not permitted where damage to shooting interests occurs'. The only exception is in the case of raptors receiving 'ordinary' protection which take many game from rearing fields; control by shooting may than be permissible under Section 4 of the 1954 Act, which requires that a Court be satisfied that the action was necessary to prevent serious damage to property. However, game in the wild is not regarded in law as property.

For mammals the law is less clear as it is described as 'scanty, imprecise and at times contradictory'. The main point emphasised is that the use of the gin trap is illegal. It is also clear from the mammal booklet that it is an 'offence to place any poison in or upon any land or building' except for destroying insects or ground vermin in the interests of public health. This should be made equally clear in the booklet on birds. 